\title{
Genetic polymorphisms within exon 3 of heat shock protein 90AA1 gene and its association with heat tolerance traits in Sahiwal cows
}

\author{
Rakesh Kumar, I. D. Gupta, Archana Verma, Nishant Verma and M. R. Vineeth \\ Division of Dairy Cattle Breeding, Indian Council of Agricultural Research-National Dairy Research Institute, Karnal, \\ Haryana, India. \\ Corresponding author: I. D. Gupta, e-mail: idgupta1959@gmail.com. RK: rakesh05vet@gmail.com, \\ AV: archana.ndri@gmail.com, NV: nish100verma@gmail.com,VMR: vineethmails@gmail.com \\ Received: 25-05-2015, Revised: 24-06-2015, Accepted: 02-07-2015, Published online: 31-07-2015
}

doi: 10.14202/vetworld.2015.932-936 How to cite this article: Kumar R, Gupta ID, Verma A, Verma N, Vineeth MR (2015) Genetic polymorphisms within exon 3 of heat shock protein $90 A A 1$ gene and its association with heat tolerance traits in Sahiwal cows, Veterinary World 8(7):932-936.

\begin{abstract}
Aim: The present study was undertaken to identify novel single nucleotide polymorphism (SNP) in Exon 3 of HSP90AA1 gene and to analyze their association with respiration rate (RR) and rectal temperature (RT) in Sahiwal cows.

Materials and Methods: The present study was carried out in Sahiwal cows $(\mathrm{n}=100)$ with the objectives to identify novel SNP in exon 3 of $H S P 90 A A 1$ gene and to explore the association with heat tolerance traits. CLUSTAL-W multiple sequence analysis was used to identify novel SNPs in exon 3 of HSP90AAl gene in Sahiwal cows. Gene and genotype frequencies of different genotypes were estimated by standard procedure POPGENE version 1.32 (University of Alberta, Canada). The significant effect of SNP variants on physiological parameters, e.g. RR and RT were analyzed using the General Linear model procedure of SAS Version 9.2.

Results: The polymerase chain reaction product with the amplicon size of $450 \mathrm{bp}$ was successfully amplified, covering exon 3 region of HSP90AA1 gene in Sahiwal cows. On the basis of comparative sequence analysis of Sahiwal samples $(\mathrm{n}=100)$, transitional mutations were detected at locus A1209G as compared to Bos taurus (NCBI GenBank AC_000178.1). After chromatogram analysis, three genotypes AA, AG, and GG with respective frequencies of $0.23,0.50$, and 0.27 ascertained. $\mathrm{RR}$ and RT were recorded once during probable extreme hours in winter, spring, and summer seasons. It was revealed that significant difference $(\mathrm{p}<0.01)$ among genetic variants of HSP90AA1 gene with heat tolerance trait was found in Sahiwal cattle. The homozygotic animals with AA genotype had lower heat tolerance coefficient (HTC) $\left(1.78 \pm 0.04^{\mathrm{a}}\right)$, as compared to both $\mathrm{AG}$ and GG genotypes $\left(1.85 \pm 0.03^{\mathrm{b}}\right.$ and $\left.1.91 \pm 0.02^{\mathrm{c}}\right)$, respectively. The gene and genotype frequencies for the locus A1209G were ascertained.

Conclusions: Novel SNP was found at the A1209G position showed all possible three genotypes (homozygous and heterozygous). Temperature humidity index has a highly significant association with RR, RT, and HTC in all the seasons. Perusal of results across different seasons showed the significant $(\mathrm{p}<0.01)$ difference in RR, RT, and HTC among winter, spring, and summer seasons. Genetic association with heat tolerance traits reveals their importance as a potential genetic marker for heat tolerance traits in Sahiwal cows.
\end{abstract}

Keywords: heat stress, heat tolerance coefficient, HSP90AA1, polymorphisms, Sahiwal cattle.

\section{Introduction}

Most part of India lies in a tropical region where temperature even goes up to $46^{\circ} \mathrm{C}$ during summer. Global warming has resulted in extensive climatic changes in tropical regions, resulting in increased heat stress in dairy animals of the region. Due to these generated pertinent heat stress to livestock, reduction of productivity with devastating economic consequences [1], decreased milk production [2], and a lower reproductive success rate [3] were seen. The loss of milk production due to heat stress in monetary terms amounts to a whopping Rs. 26616.2 million per year [4]. An increase of about $0.9^{\circ} \mathrm{F}$ in cows' body temperature has been estimated to cause $12.8 \%$ decline in conception rate in cattle [5]. Suitable breeding programs can help to achieve animal population that could cope

Copyright: The authors. This article is an open access article licensed under the terms of the Creative Commons Attributin License (http:// creative commons.org/licenses/by/2.0) which permits unrestricted use, distribution and reproduction in any medium, provided the work is properly cited. with effects of heat stress [6]. Indigenous (Bos indicus) cattle survive and perform better under heat stress as compared to temperate breeds or their crossbreds $[7,8]$ due to the high prevalence of heat shock protein (HSP) gene. Genetic differences in thermotolerance at the physiological and cellular levels are documented by a number of studies on Bos indicus and Bos taurus cattle breeds [9-11].

Cellular tolerance to heat stress is mediated by a family of proteins named as HSP. Among members of the HSP family, HSP70 and HSP90 are the most abundant proteins in eukaryotic cells. HSP90 act as important molecular chaperones that are constitutively expressed as a consequence of heat or stress induction [12]. Heat shock factor 1 is a transcription factor that is involved in the general maintenance and up-regulation of HSP90 protein expression [13]. Earlier study reported that HSP90 expression was increased due to heat stress in murine embryonic fibroblast cells [14], lung, heart, spleen, liver, and brain 
of human [15]. The "trait" heat tolerance is a quantitative trait $[16,17]$. There are two major isoforms of HSP90, which have arisen by gene duplication, HSP90 $\alpha$ or HSP90AAl (inducible form), and HSP90 $\beta$ or HSP90AB1 (constitutive form). HSP90AAl gene in Deoni cattle (Bos indicus) has been found to be polymorphic and showed significant association with productive and reproductive parameters [18]. Many earlier studies have shown an association between single nucleotide polymorphisms (SNPs) at certain HSP genes and heat resistance $[19,20]$. HSP gene families have been widely discussed as candidate genes for heat resistance [21], and few studies have shown an association between SNPs at HSP90AAl genes and heat resistance in different species.

However, no report is available on HSP90AAI gene variants and their association with thermotolerance in Indian dairy cattle breeds. Keeping in view the importance of HSP $90 A A 1$ gene, the present study was undertaken to determine the genetic polymorphism of exon 3 of HSP90AA1 gene in Sahiwal breed of cattle and to associate the observed genetic polymorphisms with heat tolerance traits.

\section{Materials and Methods}

\section{Ethical approval}

The experimental plan of study was duly approved by Institution Animal Ethics Committee of National Dairy Research Institute, Karnal, Haryana, India

\section{Resource population}

The experimental study was carried out in Sahiwal cows $(n=100)$, maintained at Livestock research complex at National Dairy Research Institute, Karnal, located at $29.68^{\circ} \mathrm{N}$ latitude and $76.98^{\circ} \mathrm{E}$ longitude with altitude ranging from 235 to 252 meters above mean sea level.

\section{Experimental animals and DNA extraction}

About $10 \mathrm{ml}$ of blood was collected in EDTA coated vacutainer tube from each of the Sahiwal cows and stored at $-20^{\circ} \mathrm{C}$ until DNA isolation. Genomic DNA was extracted from the blood samples using phenol - chloroform extraction method described by Sambrook and Russell [22] with minor modifications. The quality of DNA was checked by $1.5 \%$ agarose gel electrophoresis. Quality and quantity of DNA was also estimated by Biospec-nano spectrophotometer (Shimadzu co-operation, Japan). The ratio between $\mathrm{OD}_{260}$ and $\mathrm{OD}_{280}$ was observed for each sample. DNA sample with a ratio of 1.8 was considered good and taken for further analysis. The genomic DNA was diluted to a final concentration of $30 \mathrm{ng} / \mu \mathrm{l}$, stored at $-20^{\circ} \mathrm{C}$.

\section{Physiological parameters recorded}

Respiration rate (RR) and rectal temperature (RT) were recorded once daily for 3 days consecutively during probable extreme hours in winter, spring, and summer seasons and average was taken as final reading for association analysis. HTC was calculated based on a heat tolerance index developed by Benezra [23]. The formula is based on both RR and RT.

$$
\text { HTC: RR/23 + RT/38.33 }
$$

Temperature humidity index (THI) measures the combined effects of ambient temperature and relative humidity to ascertain heat load intensity [24]. THI was calculated for all days in three seasons viz. winter (48.77), spring (64.86), and summer (92.62) during which physiological parameters were recorded and used in the association analysis as fixed variables. THI calculation using dry-bulb temperature $(\mathrm{Db})$ and wet-bulb temperature $(\mathrm{Wb})$ to estimate the magnitude of heat stress [25], were the most common compared to other methods.

$$
\mathrm{THI}=0.72(\mathrm{~Wb}+\mathrm{Db})+40.6
$$

Where, $\mathrm{Wb}$ and $\mathrm{Db}$ are wet- and dry-bulb temperatures in ${ }^{\circ} \mathrm{C}$, respectively.

\section{Polymerase chain reaction (PCR) primers and amplifications}

Primer was designed based on the bovine HSP90AA1 gene sequence (NCBI GenBank AC_000178.1) using the Primer3 software. The sequence of primers, their respective nucleotide numbers, targeted region, and amplicon size are given in Table-1. The PCR reactions were carried out on a total of $25 \mu 1$ volume containing template DNA of $3 \mu 1$ $(30 \mathrm{ng} / \mu \mathrm{l}), 1.0 \mu \mathrm{l}$ of forward and reverse primer, PCR Master Mix (2x) (Fermentas) of $12.5 \mu 1$, and $8.5 \mu 1$ of water. Amplification was performed in a Thermal cycler (MJ research and BioRad, T100). The thermal cycling conditions involved an initial denaturation at $95^{\circ} \mathrm{C}$ for $3 \mathrm{~min}$, followed by 35 cycles with initial denaturation at $95^{\circ} \mathrm{C}$ for $30 \mathrm{~s}$, annealing temperature of $55.7^{\circ} \mathrm{C}$ for $45 \mathrm{~s}$, extension at $72^{\circ} \mathrm{C}$ for $1 \mathrm{~min}$ followed by a final extension at $72^{\circ} \mathrm{C}$ for $5 \mathrm{~min}$. PCR program for both the primers was found to be same. PCR products were detected by electrophoresis on $2 \%$ agarose gel stained with ethidium bromide.

\section{Statistical analysis}

The gene and genotypic frequencies of different genotypes were estimated by standard procedure POPGENE version 1.32 (University of Alberta, Canada) [26]. The association of SNP genotype with RT, $\mathrm{RR}$, and heat tolerance coefficient (HTC) was analyzed using General Linear model procedure of SAS Version 9.2. The significant effect of SNP variants on physiological parameters was analyzed using the following model:

$$
\mathrm{Y}_{\mathrm{ijk}}=\mu+\mathrm{T}_{\mathrm{i}}+\mathrm{SNP} 1_{\mathrm{j}+} \mathrm{e}_{\mathrm{ijk}}
$$

Where,

$\mathrm{Y}_{\mathrm{ijk}}=\mathrm{K}^{\text {th }}$ observation on RR/RT/HTC of cows in $\mathrm{i}^{\text {th }} \mathrm{THI}$ and $\mathrm{j}^{\text {th }} \mathrm{SNP} 1$

$\mu=$ Overall mean 
Table-1: Primer sequences, targeted region, and amplicon sizes of bovine HSP9OAA1 gene.

\begin{tabular}{lcccc}
\hline Primer set & Sequence (5'-3') & No. of base & Targeted region on gene (HSP9OAA1) & Amplicon size (bp) \\
\hline 1. & F- GCGTCATCACGTGTCATCTT & 20 & Exon 3 & $450 \mathrm{bp}$ \\
R- CCTCCTTTGGGTTCCAGT & 19 & $(826 \ldots . .1276)$ & \\
\hline
\end{tabular}

$\mathrm{T}=$ Effect of ith THI $(\mathrm{I}=48.77,64.86$, and 92.62) SNP1 $=$ Effect of $j^{\text {th }}$ genotype of SNP1 A1209G $(\mathrm{J}=\mathrm{AA}, \mathrm{AG}$, and $\mathrm{GG})$

\section{Results}

\section{Analysis of sequence data}

The PCR product with the amplicon size of 450 bp was successfully amplified, covering exon 3 region of HSP90AAl gene in Sahiwal cows (Figure-1). The final sequence of the contig for Sahiwal cows were deduced from the raw sequences by using BioEdit software. ClustalW software, with a reference sequence of Bos taurus (NCBI GenBank AC_000178.1) was employed for determining the polymorphism in exon3 of Sahiwal cow.

\section{SNP detection of bovine HSP9OAA1 gene}

On the basis of comparative sequence analysis of Sahiwal samples $(\mathrm{n}=100)$, transitional mutations were detected at locus A1209G as compared to Bos taurus (NCBI GenBank AC_000178.1). After chromatogram analysis, three genotypes (AA, AG, and GG) were detected at an A1209G locus. Different chromatograms showing polymorphism (SNPs) as compared to Bos taurus has been depicted in Figure-2. The allelic and genotypic frequencies of HSP90AAl gene are given in Table-2.

\section{Association of heat tolerance traits with novel SNP}

For association study RR, RT, and HTC were taken as dependent variables. Relationship of each dependent variable with THI and novel SNP variants of HSP $90 A A 1$ gene was analyzed.

Overall least square means of RR per minute, RT $\left({ }^{\circ} \mathrm{C}\right)$, and HTC were found to be $19.75 \pm 0.42,38.22 \pm 0.05$, and $1.85 \pm 0.02$, respectively (Table-3). RR per minute of each genotype were observed as AA $\left(18.40 \pm 0.46^{\mathrm{a}}\right)$, AG $\left(19.60 \pm 0.85^{\mathrm{b}}\right)$, and $\mathrm{GG}\left(21.18 \pm 0.64^{\mathrm{c}}\right)$ and $\mathrm{RT}\left({ }^{\circ} \mathrm{C}\right)$ of each genotype AA $\left(37.91 \pm 0.12^{\mathrm{a}}\right), \mathrm{AG}\left(38.32 \pm 0.10^{\mathrm{b}}\right)$, and GG $\left(38.27 \pm 0.08^{\mathrm{b}}\right)$ were observed during winter, spring, and summer seasons. The corresponding values of HTC of each genotype, AA $\left(1.78 \pm 0.04^{\mathrm{a}}\right), \mathrm{AG}\left(1.85 \pm 0.03^{\mathrm{b}}\right)$, and GG $\left(1.91 \pm 0.02^{\mathrm{c}}\right)$ were observed in respective seasons. Perusal of results across different seasons showed the highly significant $(\mathrm{p}<0.01)$ in RR, RT, and HTC between winter, spring, and summer seasons. Overall the results revealed an increasing trend in RR, RT, and HTC with the increase in THI. On the other hand, novel SNP found highly significant $(\mathrm{p}<0.01)$ associated with RR and HTC, but with RT, low significant $(\mathrm{p}<0.05)$ was observed.

\section{Discussion}

The average RR value for locus A1209G of genotype AA $\left(18.40 \pm 0.46^{\mathrm{a}}\right)$, AG $\left(19.60 \pm 0.85^{\mathrm{b}}\right)$, and GG $\left(21.18 \pm 0.64^{\mathrm{c}}\right)$ were highly significantly $(\mathrm{p}<0.01)$
Table-2: Gene and genotypic frequencies of the patterns/variants in Sahiwal cattle population.

\begin{tabular}{llcc}
\hline $\begin{array}{l}\text { HSP90AA1 } \\
\text { gene Loci }\end{array}$ & Genotypes & $\begin{array}{c}\text { Genotypic } \\
\text { frequencies }\end{array}$ & $\begin{array}{c}\text { Gene } \\
\text { frequencies }\end{array}$ \\
\hline Exon 3 & AA & 0.23 & A 0.48 \\
& AG & 0.50 & \\
& GG & 0.27 & G 0.52 \\
\hline
\end{tabular}

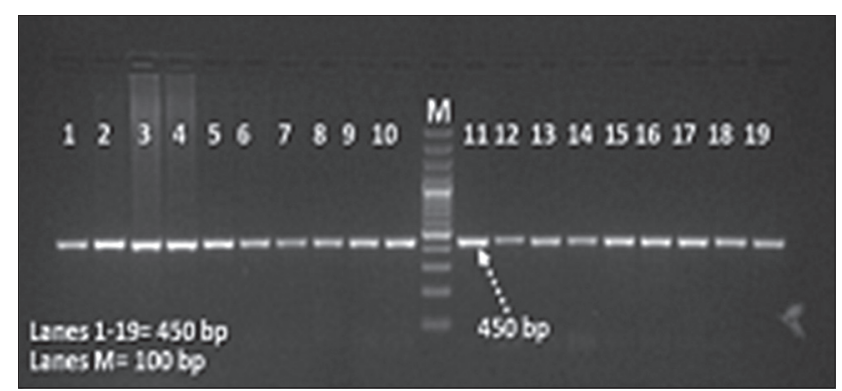

Figure 1: PCR amplification of exon 3 of HSP9OAA1 gene in Sahiwal cow (M=100bp)

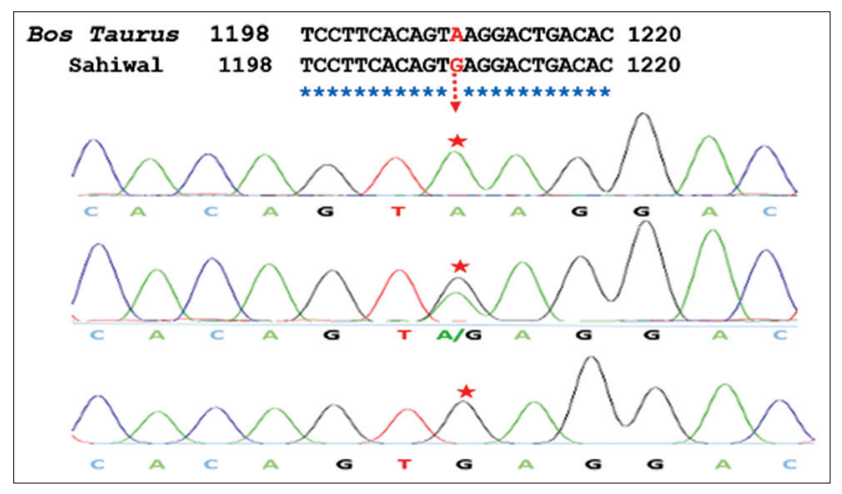

Figure 2: Chromatograph showing SNP at position 1209 $A>G$ of HSP90AA1 gene in Sahiwal cow

associated from each other. Effect of RT on SNP locus A1209G of genotype AA $\left(37.91 \pm 0.12^{\mathrm{a}}\right)$ significantly $(\mathrm{p}<0.05)$ differ with AG $\left(38.32 \pm 0.10^{\mathrm{b}}\right)$ and GG $\left(38.27 \pm 0.08^{\mathrm{b}}\right)$ genotype. Effect of HTC for genotype AA $\left(1.78 \pm 0.04^{\mathrm{a}}\right)$, AG $\left(1.85 \pm 0.03^{\mathrm{b}}\right)$, and GG $\left(1.91 \pm 0.02^{c}\right)$ differed highly significantly $(p<0.01)$ from each other. The homozygotic animals with AA genotype had lower HTC $\left(1.78 \pm 0.04^{\mathrm{a}}\right)$, as compared to both genotype AG and GG $\left(1.85 \pm 0.03^{\mathrm{b}}\right.$ and $\left.1.91 \pm 0.02^{\mathrm{c}}\right)$, respectively.

Our study indicated that Sahiwal cows of AA genotype had better thermotolerance than the other two genotypes (AG and GG) since increased respiration is an important thermoregulatory response to heat stress. It aids intemperance of excess body moisture in the expired air [27]. Higher HTC value indicated lower adaptability to heat stress in summer. In contrast, allele T at SNP g.4338 $>\mathrm{C}$ of HSP90AB1 
Available at www.veterinaryworld.org/Vol.8/July-2015/21.pdf

Table-3: Least squares means of subclasses of different fixed effects for RR, RT, and HTC in Sahiwal cows.

\begin{tabular}{lcccc}
\hline Effect & Subclass & RR** & RT* & HTC** \\
\hline Overall mean & & $19.54 \pm 0.42$ & $38.17 \pm 0.05$ & $1.85 \pm 0.01$ \\
THI & 48.77 & $14.22 \pm 0.43^{\mathrm{a}}$ & $37.92 \pm 0.05^{\mathrm{a}}$ & $1.60 \pm 0.01^{\mathrm{a}}$ \\
& 64.86 & $18.15 \pm 0.43^{\mathrm{b}}$ & $38.19 \pm 0.06^{\mathrm{b}}$ & $1.81 \pm 0.01^{\mathrm{b}}$ \\
A1209G & 92.62 & $26.26 \pm 0.41^{\mathrm{c}}$ & $38.40 \pm 0.06^{\mathrm{b}}$ & $2.16 \pm 0.03^{\mathrm{c}}$ \\
& AA (23) & $18.40 \pm 0.46^{\mathrm{a}}$ & $37.91 \pm 0.12^{\mathrm{a}}$ & $1.78 \pm 0.04^{\mathrm{a}}$ \\
& AG (50) & $19.60 \pm 0.85^{\mathrm{b}}$ & $38.32 \pm 0.10^{\mathrm{b}}$ & $1.85 \pm 0.03^{\mathrm{b}}$ \\
& GG (27) & $21.18 \pm 0.64^{\mathrm{c}}$ & $38.27 \pm 0.08^{\mathrm{b}}$ & $1.91 \pm 0.02^{\mathrm{c}}$ \\
\hline
\end{tabular}

$\mathrm{RR}=$ Respiration rate, $\mathrm{RT}=$ Rectal temperature, $\mathrm{HTC}=$ Heat tolerance coefficient, figures in parenthesis are number of animals; means with different superscripts within the column differ significantly $(* * p<0.01, * p<0.05)$

gene was found to be associated with HTC in Thai native cattle [28], Sahiwal, and Frieswal cattle in India [29,30]. Marcos-Carcavilla [31] reported a SNP located at position - 660 in the 5 'flanking region of HSP90AA1 was associated with different thermal conditions in sheep. The results of the present study were first time reported, so no earlier reports are available to compare the present findings.

\section{Conclusions}

The study was carried out in Sahiwal cows with the objectives to identify novel SNP in the HSP90AAI gene and to analyze their association with heat tolerance trait. Novel SNP was found at A1209G position and all possible genotypes were observed THI has a significant association with RR, RT, and HTC in all the seasons. The genetic variants observed in HSP9OAAI of exon 3 and their genetic association with heat tolerance traits reveals the importance of homozygotic AA genotype, which had been useful for genetic improvement of Sahiwal cow for heat tolerance traits and can also be utilized as a genetic marker to select appropriate animals for hot climatic conditions of tropics and sub-tropics.

\section{Authors' Contributions}

RK, IDG, and AV: Substantially contributed to design and plan of the study. RK and IDG: Drafted the manuscript, analyzed, and interpreted the results. NV and VMR: Helped in the analysis of data, drafted, and revised the manuscript. All authors read and approved the final manuscript.

\section{Acknowledgments}

The authors gratefully acknowledge Dr. A. K. Srivastava, Director, ICAR-NDRI, Karnal and Dr. A. K. Chakravarty, Head, DCB Division, ICARNDRI, Karnal for providing facilities to carry out the research work. Financial support provided by National Innovations on Climate Resilient Agriculture project is immensely acknowledged.

\section{Competing Interests} interests

The authors declare that they have no competing

\section{References}

1. Bernabucci, U., Lacetera, N., Baumgard, L.H., Rhoads, R.P., Ronchi, B. and Nardone, A. (2010) Metabolic and hormonal adaptations to heat stress in domesticated ruminants. Animal., 4: 1167-1183.

2. Sharma, A.K., Rodriguez, L.A., Wilcox, C.J., Collier, R.J., Bachman, K.C. and Martin, F.G. (1988) Interactions of climatic factors affecting milk yield and composition. J. Dairy Sci., 71: 819-882.

3. Cavestany, D., El-Wishy, A.B. and Foote, R.H. (1985) Effect of season and high environmental temperature on fertility of Holstein cattle. J. Dairy. Sci., 68: 1471-1478.

4. Upadhyay, R.C. (2010) 2\% Annual Milk Production Loss Due to Global Warming: Research. Press trust of India/ New Delhi $26^{\text {th }}$ September.

5. Pete, H. (2006) Improving Cow Pregnancy Success during summer's heat Horizons. Genex Cooperative, Inc. Available from: http://www. crinet.com. Pp -12:14.

6. Hoffmann, I. (2010) Climate change and characterization, breeding and conservation of animal genetic resources. Anim. Genet., 41: 32-46.

7. Collier, R.J., Collier, J.L., Rhoads, R.P. and Baumgard, L.H. (2008) Invited review: Genes involved in the bovine heat stress response. J. Dairy Sci., 91: 445-454.

8. McManus, C., Paiva, S.R., Braccini, N.J., Barcellos, J.O. and Dallago, B.S. (2013) Adaptations of cattle to stressful environments. In: Liu, G., editor. Cattle: Domestication, Diseases and the Environmental. Nova Publishers, New York, USA. p139-158.

9. Paula-Lopes, F.F., Chase, J.R., Al-Katanani, C.C., Krininger, Y.M., Rivera, C.E., Tekin, R.M., Majewski, S., Ocon, A.C., Olson, T.A. and Hansen, P.J. (2003) Genetic divergence in cellular resistance to heat shock in cattle: Differences between breeds developed in temperate versus hot climates in responses of preimplantation embryos, reproductive tract tissues and lymphocytes to increased culture temperatures. Anim. Reprod. Sci., 125: 285-294.

10. Hansen, P.J. (2004) Physiological and cellular adaptations of zebu cattle to thermal stress. Int. J. Anim. Sci., 77: 36-50.

11. Lacetera, N., Bernabucci, U., Scalia, D., Basiricò, L., Morera, P. and Nardone, A. (2006) Heat stress elicits different responses in peripheral blood mononuclear cells from Brown Swiss and Holstein cows. J. Dairy. Sci., 89: 4606-4612.

12. Chen, B., Zhong, D. and Monteiro, A. (2006) Comparative genomics and evolution of the Hsp90 family of genes across all kingdoms of organisms. BMC. Genomics., 7: 156-167.

13. Xu, D., Zalmas, L.P. and Thangue, N.B. (2011) A transcription cofactor required for the heat-shock response. $E M B O$ Rep., 9(7): 662-669.

14. Beckham, J.T., Wilmink, G.J., Opalenik, S.R., Mackanos, M.A., Abraham, A.A., Takahashi, K., Contag, C.H., Takahashi, T. and Jansen, E.D. (2010) Microarray analysis of cellular thermo tolerance. Laser Surg. Med., 42: 752-765.

15. Sareh, H., Tulapurkar, M.E., Shah, N.G., Singh, I.S. and Hasday, J.D. (2011) Response of mice to continuous 5-day passive hyperthermia resembles human heat acclimation. Cell Stress Chaperones, 16: 297-307.

16. Gaughan, J.B., Mader, T.L., Holt, S.M., Sullivan, M.L. and Hahn, G.L. (2010) Assessing the heat tolerance of 17 beef 
cattle genotypes. Int. J. Bio. Sci., 54: 617-627.

17. Li, Q., Han, J., Du, F., Ju, Z., Huang, J., Wang, J., Li, R., Wang, C. and Zhong, J. (2011) Novel SNPs in HSP70A1A gene and the association of polymorphisms with thermo tolerance traits and tissue specific expression in Chinese Holstein cattle. Mol. Biol. Rep., 38: 2657-2663.

18. Shergojry, A.S., Ramesha, K.P., Mir, A.N. and Aarif, O. (2011) Association of single nucleotide polymorphisms (SNPS) Of HSP90AA1 gene with reproductive traits in Deoni cattle. Int. J. Livest. Res., 1: 17-29.

19. Reddacliff, L.A., Beh, K., McGregor, H. andWhittington,R.J. (2005) A preliminary study of possible genetic influences on the susceptibility of sheep to Johne's disease. Aust. Vet. $J ., 83: 435-441$.

20. Liu, Y., Li, D., Huixia, Li., Zhou, X. and Wang, G. (2011) A novel SNP of the ATP1A gene is associated with heat tolerance traits in dairy cows. Mol. Biol. Rep., 38: 83-88.

21. Hoffmann, A.A., Sorensen, J.G. and Loeschcke, V. (2003) Adaptation to Drosophila to temperature extremes: Bringing together quantitative and molecular approaches. $J$. Therm. Biol., 28: 175-216.

22. Sambrook, J. and Russell, D.W. (1989) Molecular cloning: A Laboratory Manual. Cold Spring Harbor Laboratory Press, Cold Spring Harbor, New York.

23. Benezra, M.V. (1954) A new index for measures the adaptability of cattle to tropical condition. Proc. J. Anim. Sci., 13: 1015.

24. Berry, I.L., Shanklin, M.D. and Johnson, H.D. (1964) Dairy shelter design based on milk production decline as affected by temperature and humidity. Trans. Am. Soc. Agric. Eng., 7: 329-331.
25. Thom, E.C. (1959) The discomfort index. Weather-wise, 12: 57-59.

26. Yeh, F.C., Yang, R.C. and Boyle, T. (1999) POPGENE VERSION 1.31: Microsoft Window-based free Software for Population Genetic Analysis. Available from: ftp://ftp. microsoft.com/Softlib/HPGL.EXE.

27. Beatty, D.T., Barnes, A., Taylor, E., Pethick, D., McCarthy, M. and Maloney, S.K. (2006) Physiological responses of Bos taurus and Bos indicus cattle to prolonged, continuous heat and humidity. J. Anim. Sci., 84: 972-985.

28. Charoensook, R., Gatphayak, K., Sharifi, A.R., Chaisongkram, C., Brenig, B. and Knorr, C. (2012) Polymorphisms in the bovine HSP90AB1 gene are associated with heat tolerance in Thai indigenous cattle. Trop. Anim. Health. Prod., 44(4): 921-928.

29. Deb, R., Sajjanar, B. and Singh, U. (2013) Promoter variants at AP2 box region of Hsp70.1 affect thermal stress response and milk production traits in frieswal cross bred cattle. Genetics, 09: 37.

30. Sajjanar, B., Deb, R., Singh, U., Kumar, S., Brahmane, M., Nirmale, A., Kumar, S. and Minhas, P. (2015) Identification of SNP in HSP90AB1 and its association with the relative thermo tolerance and milk production traits in indian dairy cattle. Anim. Biotechnol., 26(1): 921-928

31. Marcos-Carcavilla, A., Mutikainen, M., González, C., Jorge, H., Calvo, J., Kantanen, A., Nurbiy, S., MarzanovMaría, D. and Magdalena Serrano, J.B. (2010) A SNP in the HSP90AA1 gene $5^{\prime}$ flanking region is associated with the adaptation to differential thermal conditions in the ovine species. Cell Stress Chaperones., 15: 67-81.

\section{$* * * * * * * *$}

